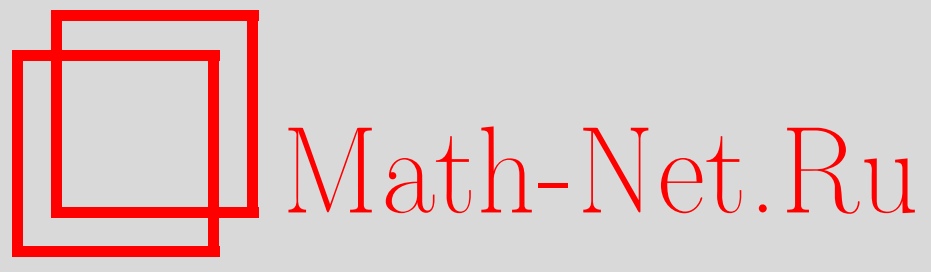

С. П. Новиков, Медали Филдса, УМН, 2010, том 65, выпуск 6, 200-203

DOI: https://doi.org/10.4213/rm9393

Использование Общероссийского математического портала Math-Net.Ru подразумевает, что вы прочитали и согласны с пользовательским соглашением http://www.mathnet.ru/rus/agreement

Параметры загрузки:

IP : 34.227 .88 .159

26 апреля 2023 г., 18:28:35

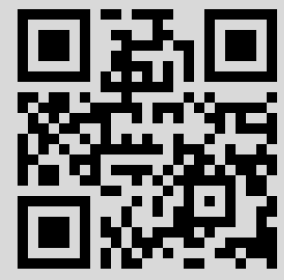




\section{Медали Филдса}

\section{Медали Филдса - 2010}

В августе 2010 г. в Хайдерабаде (Индия) состоялся очередной Международный конгресс математиков. На церемонии открытия конгресса были оглашены имена лауреатов Золотой медали Филдса. Это:

- Станислав Константинович Смирнов;

- Элон Линденштраус;

- Нго Бао Тяу;

- Седрик Виллани.

Медали были вручены Президентом Индии Пратибхой Патил. Об этих работах были сделаны доклады, опубликованные в трудах конгресса: Proceeding of the International Congress of Mathematicians, Hyderabad, India, 2010 (World Scientific). Это:

- Harry Kersten, The work of Stanislav Smirnov;

- Harry Furstenberg, The work of Elon Lindenstrauss;

- James Arthur, The work of Ngô Bao Châo;

- Hong-Tzer Yau, The work of Sédric Villani.

Состав Филдсовского комитета, согласно традиции, также был оглашен. Это Ласло Ловач (председатель), Коррадо де Кончини, Яков Матвеевич Элиашберг, Питер Холл, Тимоти Гоуэрс, Нгайминг Мок, Стефан Мюллер, Питер Сарнак, Карен Уленбек.

Ниже мы прилагаем историческую справку о Филдсовских медалях прошлых лет.

\section{Медали Филдса: историческая справка}

По инициативе Президента (1921-1924) Международного математического союза, канадского математика Дж. Ч. Филдса, были учреждены Золотые медали Филдса для лучших в мире молодых математиков (возраст которых не превышает 35 лет), не более двух медалей на каждый Международный конгресс математиков, т. е. раз в четыре года. Средства были предоставлены им же. Медаль Филдса - это довольно большая золотая медаль с изображением Архимеда и фамилией медалиста, написанной на ободке. $\mathrm{K}$ медали прилагалось также денежное дополнение. Оно было небольшим и менялось со временем.

Первые две медали Филдса были присуждены на Конгрессе 1936 г., а затем после перерыва по две медали присуждались на конгрессах 1950, 1954, 1958, 1962 гг. Советские математики не участвовали в работе Филдсовских комитетов в 1936-1954 гг.

Перед Московским конгрессом 1966 г. Устав Филдсовских медалей был изменен:

1) изменилось понятие "молодой математик" - предельный возраст был повышен до 40 лет;

2) количество Филдсовских медалей было увеличено до 4 (не более 4) в связи с увеличением числа математиков. 
Согласно этому уставу Филдсовские медали присуждаются и до сегодняшнего дня. Приведем соответствующие сведения.

1936 г. (Осло)

Медалисты: Ларс Валериан Альфорс, Джесси Дуглас.

Комитет: Франческо Севери (председатель), Джордж Биркгоф, Константин Каратеодори, Эли Картан, Тейджи Такаги.

1950 г. (Кембридж)

Медалисты: Атле Сельберг, Лоран Шварц.

Комитет: Харальд Бор (председатель), Ларс Альфорс, Кароль Борсук, Андрей Николаевич Колмогоров ${ }^{1}$, Дамодар Косамби, Марстон Морс, Морис Фреше, Вильям Ходж.

\section{4 г. (Амстердам)}

Медалисты: Кунихико Кодаира, Жан-Пьер Серр.

Комитет: Герман Вейль (председатель), Энрико Бомпиани, Флоран Бюро, Анри Картан, Александр Маркович Островский, Аке Плейель, Габор Сегё, Эдвард Титчмарш.

1958 г. (Эдинбург)

Медалисты: Клаус Фридрих Рот, Рене Том.

Kомитет: Хейнц Хопф (председатель), Оскар Зариский, Карл Зигель, Андрей Николаевич Колмогоров, Курт Фридрихс, Филипп Холл, Комараволу Чандрасекхаран, Лоран Шварц.

1962 г. (Стокгольм)

Медалисты: Джон Уиллард Милнор, Ларс Хёрмандер.

Kомитет: Рольф Неванлинна (председатель), Павел Сергеевич Александров, Эмиль Артин, Косаку Иосида, Хасслер Уитни, Клод Шевалле, Чжэнь Шен-Шень.

\section{6 г. (Москва)}

Медалисты: Майкл Френсис Атья, Александр Гротендик, Поль Джозеф Коэн, Стивен Смейл.

Kомитет: Жорж де Рам (председатель), Гарольд Дэвенпорт, Макс Дойринг, Михаил Александрович Лаврентьев, Жан-Пьер Серр, Дональд Спенсер, Рене Том, Вильям Феллер.

1970 г. (Ницца)

Медалисты: Алан Бейкер, Сергей Петрович Новиков, Джон Григгс Томпсон, Хейсуке Хиронака.

Kомитет: Анри Картан (председатель), Джозеф Дуб, Сокиси Иянага, Джон Милнор, Пал Туран, Ларс Хёрмандер, Фридрих Хирцебрух, Игорь Ростиславович Шафаревич.

1974 г. (Ванкувер)

Медалисты: Энрико Бомбьери, Дэвид Мамфорд.

Комитет: Комараволу Чандрасекхаран (председатель), Джон Адамс, Антоний Зигмунд, Кунихико Кодаира, Бернар Мальгранж, Анджей Мостовский, Лев Семенович Понтрягин, Джон Тэйт.

\footnotetext{
${ }^{1}$ Андрей Николаевич Колмогоров, чье имя присутствовало в списке членов Филдсовского комитета 1950 г., участия в работе комитета не принимал (см. кн.: O. Lehto, Mathematics without borders. A history of the International Mathematical Union, Springer-Verlag, New York, 1998).
} 
1978 г. (Хельсинки)

Медалисты: Пьер Делинь, Даниель Квиллен, Григорий Александрович Маргулис, Чарльз Луис Фефферман.

Комитет: Дин Монтгомери (председатель), Иоан Джеймс, Ленарт Карлесон, Юрген Мозер, Юрий Васильевич Прохоров, Бела Секёфальви-Надь, Жак Титс, Мартин Эйхлер.

1982 г. (Варшава)

Медалисты: Ален Конн, Уильям Пауль Тёрстон, Шин-тун Яу.

Комитет: Ленарт Карлесон (председатель), Хузихиро Араки, Поль Маллявэн, Дэвид Мамфорд, Гурий Иванович Марчук, Льюис Ниренберг, Чарльз Уолл, Анджей Шинцель.

1986 г. (Беркли)

Медалисты: Саймон Дональдсон, Герд Фальтингс, Майкл Хартли Фридман.

Kомитет: Юрген Мозер (председатель), Джеймс Глимм, Пьер Делинь, Киёси Ито, Джон Милнор, Сергей Петрович Новиков, Конджерверам Сешадри, Ларс Хёрмандер.

1990 г. (Киото)

Медалисты: Эдвард Виттен, Воэн Фредерик Рэндал Джонс, Владимир Гершонович Дринфельд, Сигэфуми Мори.

Kомитет: Людвиг Дмитриевич Фаддеев (председатель), Майкл Атья, Жан-Мишель Бисмут, Энрико Бомбьери, Кенкичи Ивасава, Питер Лакс, Чарльз Фефферман, Игорь Ростиславович Шафаревич.

1994 г. (Цюрих)

Медалисты: Жан Бургейн, Ефим Исаакович Зельманов, Жан-Кристоф Йоккоз, Пьер-Луи Лионс.

Комитет: Дэвид Мамфорд (председатель), Сриниваса Варадан, Луис Кафарелли, Масаки Кашивара, Барри Мазур, Деннис Сулливан, Александр Схрейвер, Жак Титс.

1998 г. (Берлин)

Медалисты: Ричард Юйн Борчердс, Уильям Тимоти Гоуэрс, Максим Львович Концевич, Кёртис Т. Макмуллен.

Комитет: Юрий Иванович Манин (председатель), Джон Болл, Йоханнес Дюйстермаат, Джон Коутс, Роберт Макферсон, Киёдзи Сайто, Стивен Смейл, Йорг Фрёлих, Майкл Фридман.

2002 г. (Пекин)

Медалисты: Владимир Александрович Воеводский, Лоран Лаффорг.

Kомитет: Яков Григорьевич Синай (председатель), Джеймс Артур, Спенсер Блох, Жан Бургейн, Ефим Исаакович Зельманов, Ясутака Ихара, Герберт Лоусон, Сергей Петрович Новиков, Джордж Папаниколау, Хельмут Хофер.

2006 г. (Мадрид)

Медалисты: Венделин Вернер, Андрей Юрьевич Окуньков, Григорий Яковлевич Перельман, Теренс Тао.

Комитет: Джон Болл (председатель), Энрико Арбарелло, Мишель Вернь, Герхард Гуйскен, Дональд Доусон, Кёртис Макмуллен, Алексей Николаевич Паршин, Том Спенсер, Джеф Чигер. 
2010 г. (Хайдерабад)

Медалисты: Седрик Виллани, Элон Линденштраус, Станислав Константинович Смирнов, Нго Бао Тяу.

Комитет: Ласло Ловач (председатель), Тимоти Гоуэрс, Коррадо де Кончини, Нгайминг Мок, Стефан Мюллер, Питер Сарнак, Карен Уленбек, Питер Холл, Яков Матвеевич Элиашберг.

Первым из советских математиков Филдсовской медали был удостоен С. П. Новиков в 1970 г. Математическая школа бывшего СССР/России представлена среди Филдсовских медалистов следующими именами: С. П. Новиков (1970), Г. А. Маргулис (1978), В. Г. Дринфельд (1990), Е. И. Зельманов (1994), М. Л. Концевич (1998), В. А. Воеводский (2002), А. Ю. Окуньков и Г.Я. Перельман (2006), С. К. Смирнов (2010).

Из них С. П. Новиков (1970) и Г. А. Маргулис (1978) не были допущены до участия в конгрессе и церемонии вручения медалей по инициативе Председателя Национального комитета советских математиков, директора института им. В. А. Стеклова, И. М. Виноградова, по ненаучным мотивам, характерным для советского периода.

Из всех Филдсовских медалистов, вышедших из советской/российской математической школы, лишь С. П. Новиков, Г. А. Маргулис, В. Г. Дринфельд и Г. Я. Перельман проживали и работали в СССР/России в момент присуждения медали. Остальные уже работали в различных странах Запада.

Распределение Филдсовских медалистов по научным школам таково:

- С. П. Новиков, Г. А. Маргулис, В. Г. Дринфельд, М. Л. Концевич, В. А. Воеводский и А. Ю. Окуньков - московская научная школа;

- Е. И. Зельманов - новосибирская научная школа;

- Г. Я. Перельман и С. К. Смирнов - ленинградская (санкт-петербургская) научная школа.

О работах всех Филдсовских медалистов на соответствующих конгрессах знаменитыми учеными были сделаны доклады. В начале этой статьи сообщено, кто делал доклады о медалистах 2010 г. Доклады о медалистах 1936-1994 гг. можно найти в кн.: Fields medallists' lectures, World Sci. Ser. 20th Century Math., 5, eds. M. Atiyah and D. Iagolnitzer, World Scientific, Singapore, 1997. Было бы целесообразно опубликовать все доклады о медалистах, начиная с 1936 г., в русском переводе в виде книги. Здесь мы приведем лишь имена ученых, сделавших доклады о работах советских (российских) медалистов до 2006 г.:
о работах
С. П. Новикова (1970) - М. Ф. Атья (М. F. Atiyah);
о работах Г. А. Маргулиса (1978) - Дж. Титс (J. Tits);
о работах В. Г. Дринфельда (1990) - М. Джимбо (М. Jimbo);
о работах Е. И. Зельманова (1994) - У. Фейт (W. Feit);
о работах М. Л. Концевича (1998) - К. Г. Таубс (С. Н. Taubes);
о работах В. А. Воеводского (2002) - К. Суле (С. Soulé);
о работах А. Ю. Окунькова (2006) - Дж. Фелдер (G. Felder);
о работах Г. Я. Перельмана (2006) - Дж. Лот (J. Lott).

В 1992 г. был издан сборник статей Филдсовских медалистов о науке "Mathematical research today and tomorrow: Viewpoints of seven Fields medallists", Lecture Notes in Math., 1525, eds. C. Casacuberta and M. Castellet, Springer, Berlin, 1992 (статью С. П. Новикова "Role of integrable models in the development of mathematics" в этой книге см. на сайте http://www.mi.ras.ru/ snovikov). 